Historic, Archive Document

Do not assume content reflects current scientific knowledge, policies, or practices. 


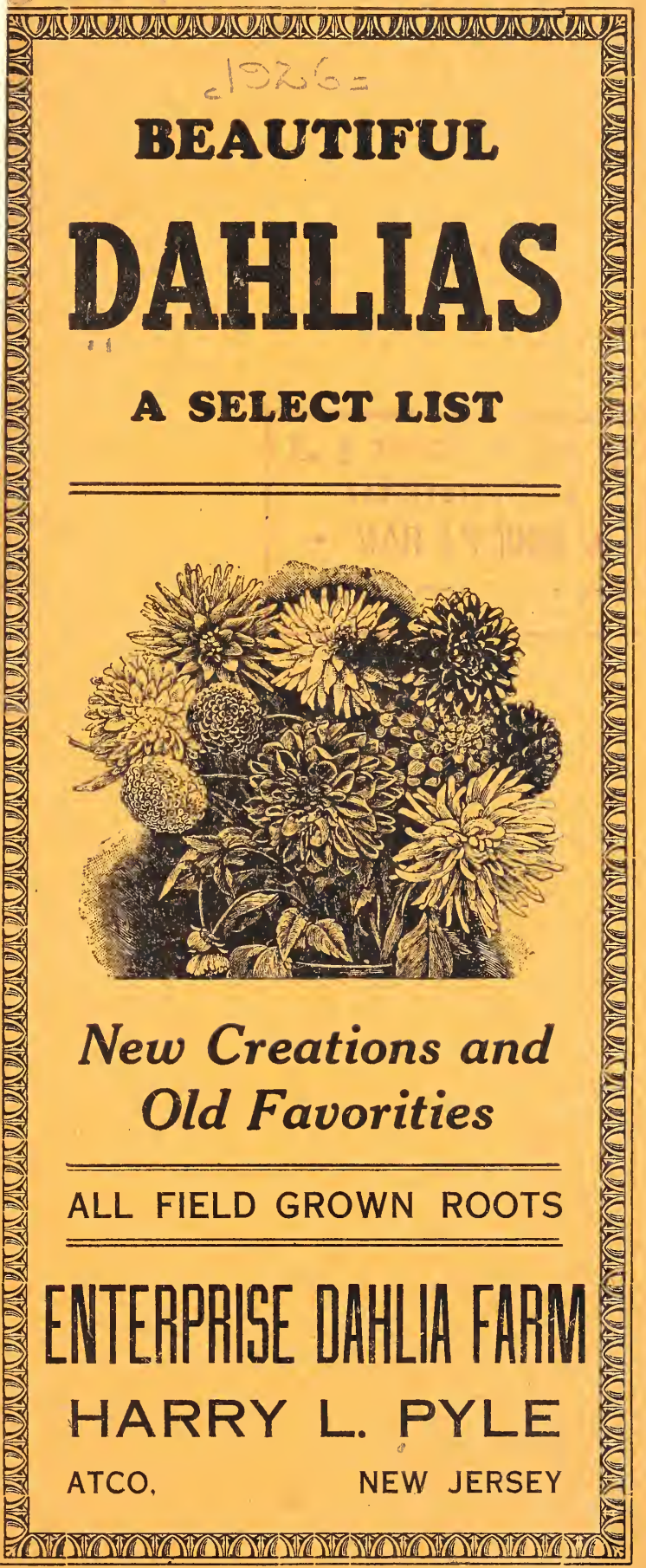




\section{Just A Word}

To My Friends and Patrons:

I take pleasure in presenting to you my annual dahlia catalogue containing a select list of choice varieties, including many of the latest creations in the dahlia world; also a goodly number of old favorites.

Thanking you all for past favors, and hoping for a continuance of your patronage. I will strive to please by sending out only the best stock and giving prompt service.

Always at your service,

Sincerely yours,

HARRY L. PYLE, Atco, N. J.

\section{Please Note}

ORDERS SHOCLD BE SENT FARLY-Thus enabling us to ship promptly. They will be booked and delivered in the order in which they are received.

ALWAYS GIVE FULL ADDRESS-This is rery important. yet is sometimes omitted by our customers. Piease write your name and address plainly.

REMITTANCES-May be made by Express Money Order or P. O. Money (Order. If stamps or cash send in Registered Letter.

OCR TERMS-Ale cish with arder.

FORIVARIDING - All the Dahlia poots listed in this adalogue are sent by mail postpaid. 


\section{CHOICE DECORATIVE DAHLIAS}

This class is very popular. The largest flowering dahlias, those producing the immense blooms which grace the exhibition table at the dahlia shows, are nearly all to be found among the decorative varieties. Great advancement has been malle the past few years through the California productions.

A.MERICAN BEACTY. Bright arminom, very large Perfectly double flowers. produced on long stiff stems, well above the foliage. Worthy of the name.....25e

AMIX RA. A new variety. very large flowers of copper and orange, with a reflex of scarlet. Has won many prizes. Will bloom freely all season.........\$3.00

IVESHA. Immense size, clear light yellow. Beautiful regular form. fine for exhibition purposes......... 250

BASHFLL GIAN'T. Yellow. shaded apricot, producing Howers 10 inches in diameter. An exhibition variety of great merit ..................\$2.00

BLOOMHOVE. Another immense flower that attracts attention. (Year violet rose color. with long reflexed

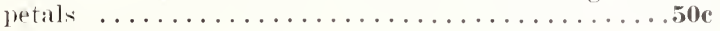

BICE OBBAN. Still one of the nearest approaches to blue in the tahlia world. An old favorite .............

BREAK OF DAY. I new ant flowered dahlia of a delicate clear sulphur vellow. tinting to sulphur white at the tips the flowers have a beautiful waxy appearance. 1 strong grower and a free bloomer ...............

BREEZELA WN. Dazzling rermillion. Immense size, perfect form, full center. Early bloomer........750

CARMENCITA. A beautiful fancy decorative with enormous blooms of a rich deep vellow. regularly striped red ........................\$1.00

CRIMSOn KING. Richest glowing red, fine form, very

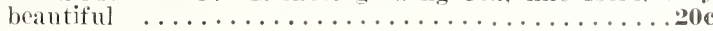

CUBAN GIANT. Deep crimson, shated maroon. Im-

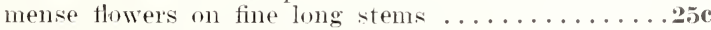

DELICE. Still one of the loveliest of its class. Color a bright luminous pink, entirely distinct, a pleasing

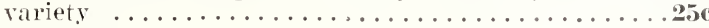

DR. TEVIS. One of the largest dahlias grown. color bronzy old go!d, shaded and suffused violet rose. flowers borne on long stiff stems. Fine for exhibitions. A dahlia of real merit .....................

DR. TYRELL. Giant flowers, rich golden bronze. A favorite autumn slade ..................25e

DREAM GIRL. I new variety with a new color combination. Pale lemon vellow at base of petals. slatling to rose red at tips, refiex pink and white. A beautiful dahlia and entirely distinct ............\$\$.00

EARL WILLIAMS. Scarlet, tipped white, giant flow ers, deep and regularly formed, on fine long stems. A fine bloomer ......................51.50

FANTASIE. A new acquisition that promises to become a universal favorite. Flowers large and of a new and distnict color among dahlias. Salmon, shaded blue. A very prolific bloomer
FIRE BURST. Beantiful glistening red, immense flow ers, on long stems. A variety of great merit......35

FLAMINGO. A unique dahlia of distinet form. with broad wavy petals, color a rich deep crimson red. Bean-

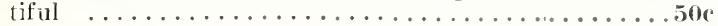

GOLD MINE. An ideal dahlia. pure golden yellow, large. perfect form, full high center and a wonderful bloomer.

$30 \mathrm{C}$

GRANI DUKE ALENIS. P'ure white, lightly erlged lavender pink. A large magnificent flower with decibly

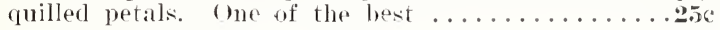

HORTELANUS FIE'T. One of the loveliest dahlias that ever come from IIolland. 'The color is a creamy salmon. slading to soft rellow. The flowers are large and the formation and stems are both excellent. Free flower-

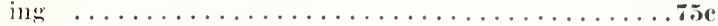

HORTCLANUS WITTE. Very large. pure white. with good stems. One of the best ..................

INSULINDE. The finest and most artistic dahlia, of distinct form, with petals twisted and curled. Color a rich saffron yellow, shaded russet orange. Stems "2 to :" feet long. A grand introduction ...........\$1.00

ISABEL STREET. A new variety that has attacted great attention. Color bright rellow, sharled rose red with white tips, reflex pale pink. A splendid exhibition dahlia ..........................\$2.0. . . .

JACK ROSE. That brilliant crimson that marle the Jack rose popular and suggests the name........15c

JAN OLIESL IGER. Tery large, pure yellow flowers on exceptionally strong stems . . . . . . . . . . . ssc

JEANNE CHARMET. Iheautiful bright pink, edged crimson, free blonmer, large flowers. Attractive...zbc

JUDGE MAREAN. I variety of exceptional merit. The color a beautiful combination of salmon pink, red. orange and rellow. Immense flowers produced early and freely throughout the season ...........\$1.75

IRIG ALBER'T. Immense flowers. with beatiful curled and twisted petals. arraved in real kingly color. Rich royal purple. A prize winner ............

J. LIDDE PENNoCK. The largest rich plum colored decorative dahlia, both for size and depth of flower. Worthy of a place in your dahlia garden .........35e

LA MASCOT'TE. In attractive variety, with a very remarkable color contralst, petals silvery white, with a violet red reverse. Very large flowers and a free bloomer .......................\$ะ.00

LE GRAND MANITOC. An extra large showy variegated decorative dahlia. Pink striped crimson.....25e

L. K. PEACOCK. The idleal pure white. splendid form early, free and continuous bloomer. Reliable.....35e 


\section{CHOICE DECORATIVE DAHLIAS-Continued}

LEMON GIANT. Immense flowers, clear lemon yellow. $20 \mathrm{c}$

LORD PENN. A handsome quilled dahtia of a beautiful

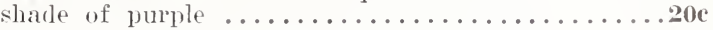

MAID OF IENT. Cherry red, tipped white. An old

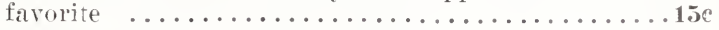

MAIDEX BLCSH. Large showy flowers, clear yellow at base of petals, passing to primrose, overlaid and suffused pink. Fine firm leaf foliage. Excellent bloomer.

$50 \mathrm{c}$

MARIANNE. Large maroon flowers, heavily tipped white. Attractive .................

MANITOC. A dwarf variety, producing giant flowers of an exquisite amber bronze shade............25c

MILLIONAIRE. Immense flowers. lavender pink, tint ing to white at center. One of the finest and largest for exhibition purposes ................

IINNIE BLRGLE. A splendid variety. Originated h, Mr. Burgle, gardener at the Mare Island Navy Yard. color rich cardinal real, large, fine form. strong. vigorous grower, flowering freely on long stiff stems........30c

MINNIE McCOLLOUGH. I beautiful combination of autumn shades. the red and gold of autumn leaves. A

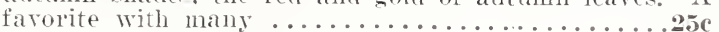

MME. LE NORMAND. A very striking and pleasing rariety. large Howers, rich clear rellow, pencied and striped bright red. Extremely free bloomer. A real

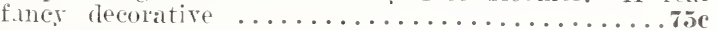

MIIE. MARZE. I'ure white, giant Howers of fine form. produced freely on long. stiff stems...........40

MIIE. VANDENIDEAL. Beautiful silvery pink, with

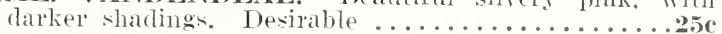

IIT. BLANC. Large snow white. Reautiful formation.

$25 \mathrm{c}$

IIRS. CARL SILSBICH. Verr large. A beautiful mature pink, tinting to white at center. Extremely long stems ........................

MRS. C. H. IBRECK. Soft yellow. suffused and tinted crimson. bright and effective, large flowers on stiff erect

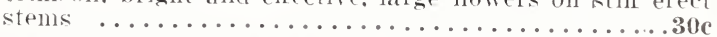

MRS. I. IDE VER IVARNER. One of the most wonderful dahlias in cultivation. I strong open grower, giant Howers. color a bright lilac rose. W'ill give satisfaction.

$\$ 2.00$

IRS. J. G. CASSETT. Bright cerise pink. large flowers

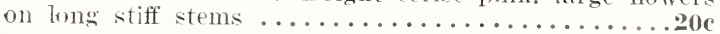

IIRS. J. HARRISON DICK. The dahlia supreme. One of the most valuable new varieties of recent introduction. Color citron yellow at center. onter petals suffused and overlaid salmon rose. A lovely and effective combination, producing perfect flowers in the greatest profusion on long. stiff, erect stems............5c

MRS. ROOSEVELT. Immense soft pink blooms on exce!lent stems. A beautiful flowrer with quilled petals. zoc

MRS. IV. E. ESTES. A grand new white dahlia. Tery large, fine form $\ldots \ldots \ldots \ldots \ldots \ldots \ldots \ldots \ldots . \ldots \ldots$
ORANGE BEALTY. Rich orange scarlet. A wonderful

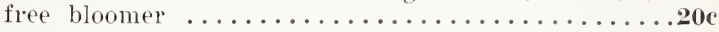

ORANGE PERLE. Rich orange, tipped white.....25c

OREGON BEAC'TY. Bright vermillion cardinal, rich and glistening. large flowers, on long graceful stems. 30c

PAPA CHARMET. Deep coral red, overlaid relvetr maroon, the color effect being a rich crimson maroon.

$30 \mathrm{c}$

PATRICK O'MARA. This sensational new variety was awarded a gold medal by the Amercan Dahlia society as the best autumn shade variety in existence. Color a p.easing shade of orange buff. slightly tinted rose. Very large flowers on long, erect stems..........

PINI FLAMINGo. Large violet rose flowers, every one with a perfectly full center. A free bloomer on long stems. Highly recommended ............ soc

PINI JACK ROSE. A silvery sport of Jack rose. De-

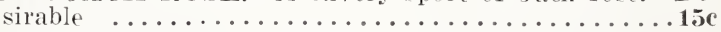

PRIDE OF INDIA. Large perfectly formed flowers, beautiful shade of purple, tipped white ..........30c

PRINCE OF ORA IGE. A gimt flower 7 to 9 inches across, rich orange. shaded scarlet. The flowers are produced on magnificent stems. held high above the foliage ........................ soc

PRINCESS PAT. Flowers are very large, of perfect form on good stems, color a very pleasing shade of old rose ....................... 1.00

PROF. MANSFIELD. A giant decorative of most unique coloring. A pleasing combination of yellow, red and

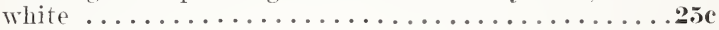

QLEEN MARI. An ideal pink. In improvement over Delice. Al larger flower. stronger grower. Full round-

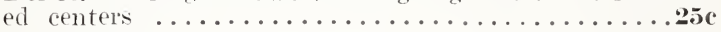

RED DUKE. Very large, rich dazzling red, splendid form. quilled petals, a red Grand Duke Alexis.....25c

SEQTOIA GIGANTIA. Well named, a grand variety with immense blooms of a buttercup yellow, with a suggestion of red ...................\$1.00

SHCDOW'S LAVENDER. Reautiful silvery lavender. finely formed giant flowers on good stems. Has attractive lace-like foliage. In great demand........\$2.50

SOLV DE GLS DUZON. Soft scarlet red bloome $T$ to 9 inches across. Worthy of a place among the giants. $\mathbf{2 0 c}$

SNOWDRIFT. Large pure white deep flowers, with broad waxy petals .................\$1.00 STUNNER. Very large soft yellow blooms of finest form and borne erect on stout stiff stems. One of the

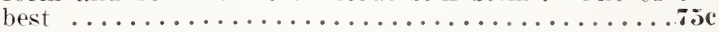

THE I. S. A. Immense deep orange blooms of unusual formation which makes it very artistic. Good stems and a free bloomer ................\$1.00

VARIABILIS. I grand variety of large size and fine form. with tips of petals cleft, color a rich bronzy

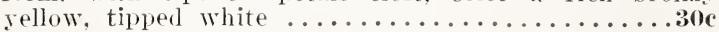

ZULU. The black dahlia.................... 


\section{BEAUTIFUL CACTUS DAHLIAS}

In this section are listed both the true cactus and the hybrid cactus varieties. In the true cactus type the petalo an mosty long and very narrow. In sone varioties the potals are straight. in others they are curled, twisted, inthrel and reflexed. giving to each a distinct individuality, very attractive, reminding one of the chrysanthemum. The hybrid atetus have shorter and broader petals. bordering on to the decorative type.

ITTRAC'TION. (Hybirl cactus.) Large elegant flower of a coatr violet rose. on lomg stiff stems. I dillial of

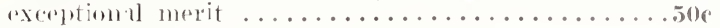

MVMaNCHE. Very large of heary formation, pure White, cxtral loug stems. The of the best.......

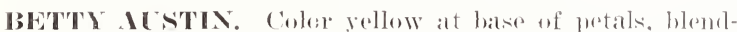
ing to rose carmine, yellow at tips. The ideal hybris] ractus. Entively distinet. Should be in avery collece

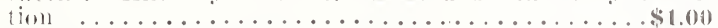

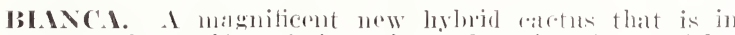

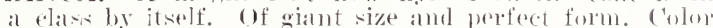
a soft miuve pink. I very free hlowmer........... . .

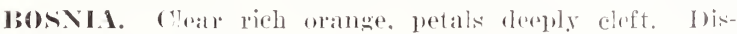

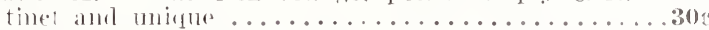

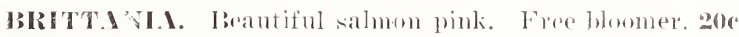

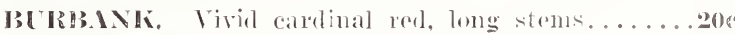

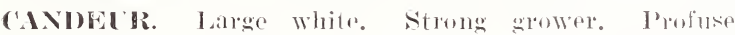

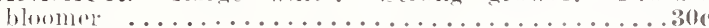

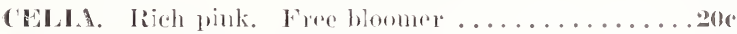

CHAS. ClR'TIS. Iatrge crimson flowers. beantiful lomg. nalrow, incurved petals. Fine .................

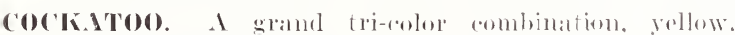

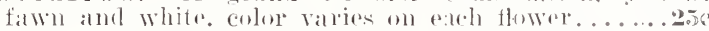

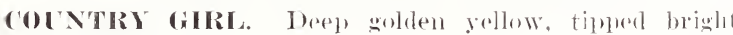

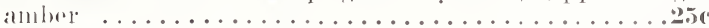

COMRIIDE. A vory pleasing valiety, froducing alear silmon pink fiower's freply on lomg, stiff strms. . . . 150

CRISTII. A clear silvery pink, beantiful incurved petaks. I real gem among dahlias................

I).HILIMLM. A real novelty, rich, crealmy white Howers, resembling a chrysanthemum ..........

D.MINTY A beantiful blembling of colors. yellow, sal-

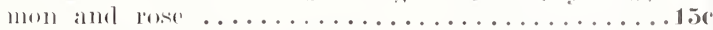

DICHESS OF MARLBORO. A migniticent actus, rich wolden orange. oveltad solferino. I'loasing amb

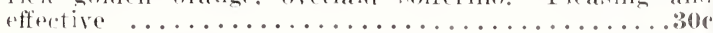

ECHO. Iallese beautiful flowers of a distinet slate of rose, suffused crimson. Very attractive...........

EDITH CMRTER. Soft bright yellow. hearily tipped bright rosy carmine, fine form, good size, fres and (onthtinuous bloomer on long stems ............. . ofo

HIECTRIC. Canary rellow, heavily tipped white, deli-

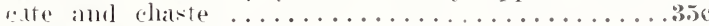

WXCEISIOR. Very dark rich velvety marem, preulian

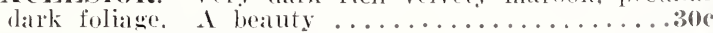

FAIRY QUEEN. A pure white, with lomg lound in-

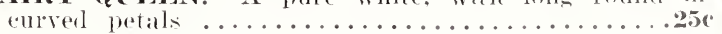

FIoRA DOR. I'ure garnet, profure bloomer. An old

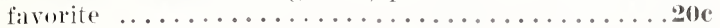

FIARII). Large bright searlet flowers on lomg stems.

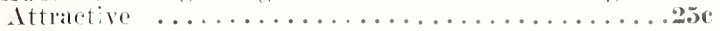

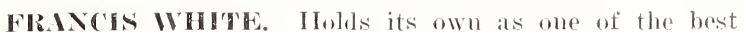
white cactus. botle for form and purity of color ...250

F. W. WEILODS. Fowers of immense size, with lome narrow incorved petals of a livaly omatnge searlet. One of the largest and finest antmmu shade varieties. I

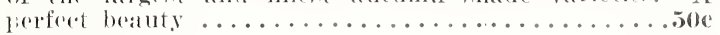

G.ILITES. Violet rose. with matuve sharlingis. Neat

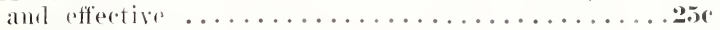

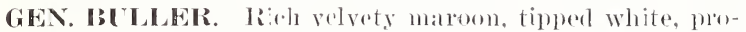
fuse bloemer, lomestoms ......................

GLIIDS SHEIRUOI). (Hybrid calctus.) IBeautiful pure white flowers on lome. stiff strms. ()ne of the

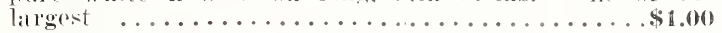

GLORS OF WIITS. Rich anary vellow, fine incurverl petals, blooms pofusely on gool stoms. Beautitul. 300

GOLD IAND). (folden yellow, plants are literally covered with flowers. Fine ..............250

GOLDEN WMGLE. Bright yellow, suffused rose and

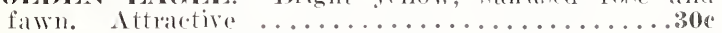

GOLIDEN GATH. (IIybrid actus.) Immense flowers. golden yellow, shaded fawn. Very showy........25e

GOLIDEN WEs'T. Rich gohlen bromzy vellow. I splendirl commereial and garden vartety ................

GRAPHIC. Richest erimson matom, tiphed white, long pointed incurved petals. I) istinct and striking..... soc

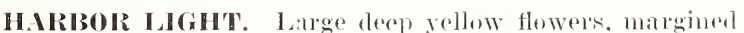

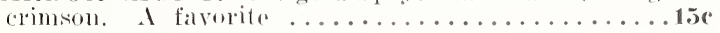

H. L. Brodsson. Inose with white center. A beautiful

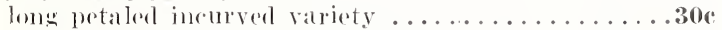

H. SHOESMITH. Brilliant sarlet, straight noedle-like

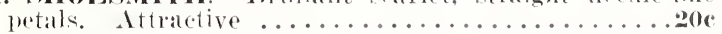

H. W. SHLIEM. Jirght armson, large showy flowers.

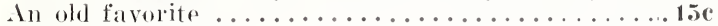

I0LANTHE. Very latege. long guilled inempod petals. deep cor'al red, tipped goiden yellow. I bistinct.....25c

J. B. BRIAN'T. Extra large light yellow flowers with long. narrow, twisted and incurved petals. I fine ex-

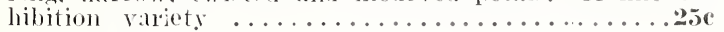

JERNY WREN. A fine shate of vellow, suffused and

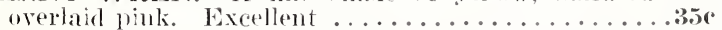

J. H. JACKSON. Rich velvety maroon, large flowers and a free blowmer. (Jus of the best and most reliable

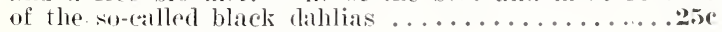




\section{BEAUTIFUL CACTUS DAHLIAS-Continued}

JOHX RIDING. Rich crimson flowers of immense size and depth. petals long, narrow and straight. A real

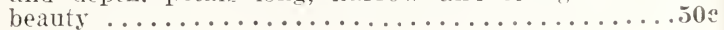

JLGEND. Peautiful curled petals, pure wlite tinted

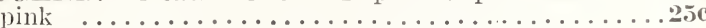

KALIF. (Hrbrid cactus.) scarlet red. producing giant flowers freely on long, stiff stems. The most popular red cactus dahlia today. Gives universal satisfaction. joc

KREINHILDE. Deep cerise pink, tinting to creamy pink at center. A valuable variety, as the flowers keep a

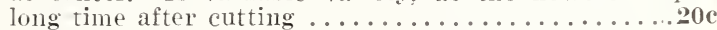

LA FAVORITA. A grand new dahlia of distinct coloring. Ieautiful brilliant salmon chading darker at center and liohter at tips; al ileal flower

LADY FAIR. Primrose, tinted pink. long deeply cleft incurved petals. Very pretty ...................

LAWINE. White. lightly suffused pink on reverse side of petals. Profuse bloomer ...................

LIBEILE. Beautiful deep rose purple flowers with full centers. A continuous bloomer ..................

LCSTRE. An early free blooming scarlet rermillion.

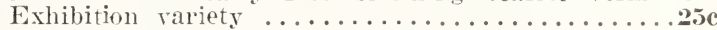

MAGPIE. Maroon tipped white, some pink tipped white and some solid maroon flowers on same plant. At-

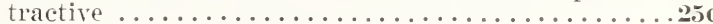

MARGARE'T BOLCHON. Bright pink tinted to flesh pink at center. A charming rariety ............5c

MARJORIE CASTLETON. Handsome rose pink. Tery profuse bloomer. Dependable .................

MARY PURRIER. A splendid bright red of large size and long narrow incurved petals...............35c

MARY STEFFERSON. (Hybrid cactus.) Large size, full form and craceful, color citron yellow outer half of petal creamy white, both yellow and white mottled and overspread with rosolane pink. Should be in every collection

MELODY. Very large, with long narrow incurved petals. color canary yellow, tipped white..................

MISS PERIiIs. White, rellow and fawn. A fine tri-

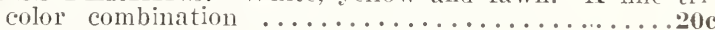

MORNING GLOW. Soft golden yellow, tipped bronzy amber, large, fine form and profuse bloomer.......25

MIIE. ESCHENAUER. An ideal dahlia, being yellow at base of petals, passing to creamy white, suffused and tipped pale lilac. Delicate and chaste............30c

MRS. FDNA SPENCER. (Hrbrid cactus.) An exceptionally fine variety, color silvery lilac, shading to bright orchid pink, large, fine form, good stems and a free bloomer .............................

MRS. G. WYATTE. Beautiful snow white flowers on long stiff stems, long fine incurved petals. A grand

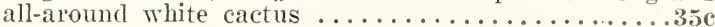

MRS. WAARsER. (Hybrid cactus.) Mammoth size, fine form and substance, color creamy white with apple

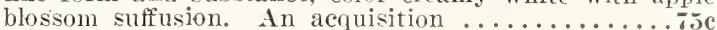

NIBELLNGENHORT. (Hybrid cactus.) Rich golden apricot. suffused old rose, producing massive flowers early and freely on very long stiff stems. A prize

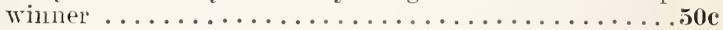

PIERRO'T. Immense s:ze with rery long incurved petals. deep amber. distinctly tipped white. A magnificent ex-

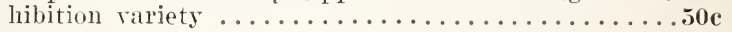

PINK PERLE. Bright rose pink, lighter at tip of petals. Early and profuse ..................20e

PRINCE OF YELLOW. Deep canary rellow. A good

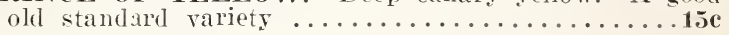

QUAKER CITY. The flowers are large with 3 to 6 smaller petals at the base of the large petals. producing a most artistic effect, color clear primrose yellow...50c

QLEEN OF HEARTS. Pure white, yellow at base of

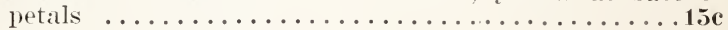

RED CROSS. (Hybrid cactus.) A beautiful combination of red and yellow shades, large fine form. extra

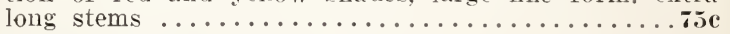

REINE CAYECX. Rich glowing red. Extremely pro-

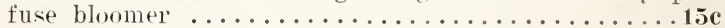

ROSY MORN. Beautiful peach blossom pink.......15e

RUBE GIRL. Color soft rellow. suffused, overlaid and tipped coral red. A remarkable bronzy or autumn shade

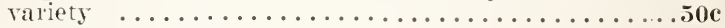

SEQLOIA. Golden bronze, good size and form. A free

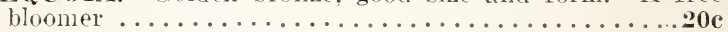

SHERLOCK. Bright orange cinmamon. A distinct color

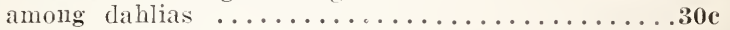

SOVEREIGNTI. Large, pure yellow, full center. long narrow straight petals ....................

SUCCESS. One of the best. clear yellow, with long pointed petals. A continuous bloomer...........25c

SUNSET. Yellow, shading to apricot. Full and free

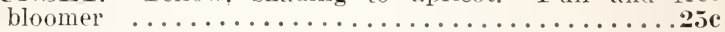

SIVEET BRIAR. A beautiful incurred variety of a lorely slade of soft pink. Will please all who grow it. $25 c$

THE LION. One of the largest yellows. shaded salmon

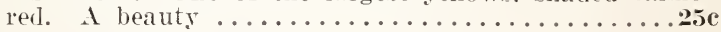

THE QCAKER. White, tinted flesh pink. finely formed Howers on wiry stems in abundance ...................

TOM LUNDY. (Hybrid cactus.) Very large rich red with darker shadings, of recent introduction ..... 60c

TRICOLOR. (Hybrid cactus.) Yellow. tipped white, with red blotch on center of petals. Distinct and at-

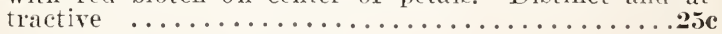

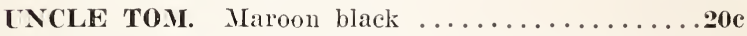

WODAN. Salmon rose. shading to old gold at center.

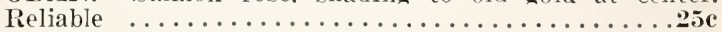

YELLOIV KING. Immense light vellow flowers on long stems, with long twisted petals, artistically arranged. 35c 


\section{Wonderful Paeony Flowered Dahlias}

This is one of the newer types, also called the art or artistic dahlias. The true type resembles the Japanese paeony. Flowers semi-double. The inner petals have a more or less irregular formation, being usually curled or twisted. Very profuse bloomers on long stems.

AUTUMN GLOW. A most distinct and striking autumn shade variety. A lovely combination of yellow, buff and

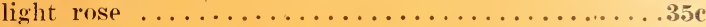

CALIFORNIA. Large golden yellow flowers, early and profuse flowering ....................

CLEOPATRA. Deep yellow, the reverse of the petal, shaded bright tangarine. Pleasing and attractive. \$1.50

CREAM KING. A beautiful pale yellow of exquisite form. Farly, free and continuous bloomer......25c

DIANA. Very large, rich glowing crimson blooms on long stiff stems .....................

DIEMONT VON BISTEIN. Large, white, suffuser and shaded blue lilac. Very fine form and a free bloomer . . . . . . . . . . . . . . . . . 25e

GEISHA. Noted for its distinct and striking color combination. Golden yellow, changing to briglit red at the center of petal and back again to gold at tins. Giant flowers on long wiry stems ................50c

GOLDEN SUNSET. Yellow, tinted rose..........25e

JOHN D. ROCKEFELLER. A fine salmon buff. Very free bloomer of well formed flowers on long strong

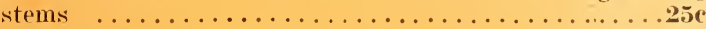

JOHN WANAMAKER. A tine example of the paeony type of clahlia. Flowers have a very attractive formation. Color a distinct sharle of rose lake.
MME. J. COSSARD. Very large flowers of charming color effect, bright rosy crimson, with a pure white zone around the yellow disc. Pretty ..............

MRS. WM. KERR. Rich cream, suffuser pink, overlaid bright crimson. Tery effective.................

QUEEN ELIZABETH. A grand new paeony dahlia of the highest type, in color a beautiful rose mauve. Very large flowers on loug slender yet stiff stems -21/2 to 3 feet long. In great demand ...............

QUEEN WILHELMINA. Beautiful glistening snow white large tluffy Howers. A charming variety that still holds its own among the white paeony dahlias. 25e

ROSE BEAUTY. Bright rose color, large flowers, center petals curled and twisted. Very pretty......50c

ROSALIA STYLES. A collosaal paeony. The largest and best pink of this class. Color bright tyrian pink, tipped lighter reflex pink. A superb variety that has attracted great attention .............\$1.00

SENSATION. Bright scarlet, heavily tipped snow white. A strong vigorous grower and profuse bloomer...25e

SNOW FLAKES. Extremely prolific. The plants are literally covered with large snow white blooms....25c

VARIEGATED LISTZ. Dark Oriental red with yel'ow tips and markings. I superior variety for decorations.

\section{SPECIAL DAHLIA OFFER 12 Choice Dahlias-All Different}

Named and Labeled-Including Cactus, Decorative, Paeony and Show Dahlias $\$ 1.00$ Postpaid

15 CHOICE DIFFERENT DAHLIAS

(Not Labeled) $\$ 1.00$ Postpaid 



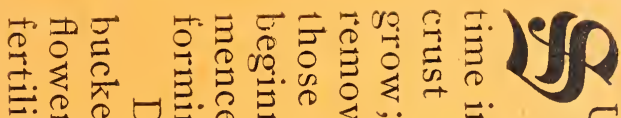

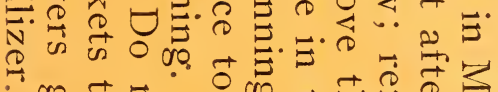

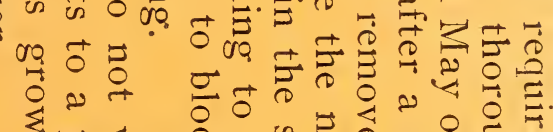

यद

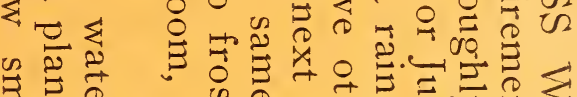

政

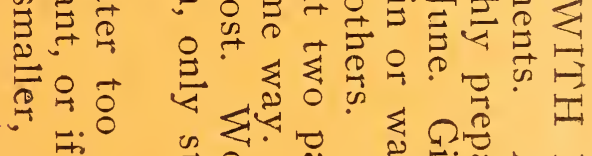

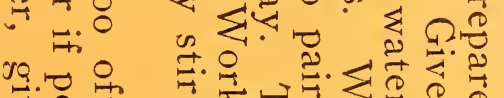

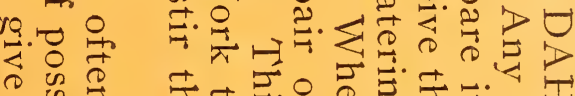

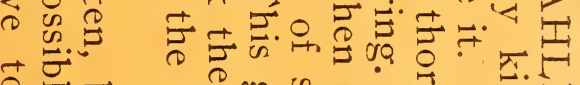

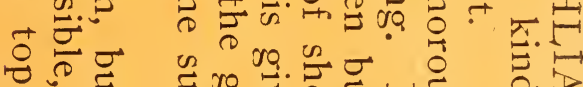
舟 $\Rightarrow \begin{aligned} & \text { ro } \\ & 0\end{aligned}$

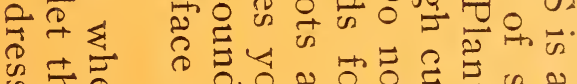

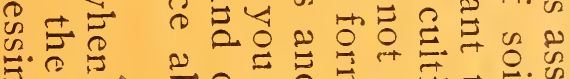

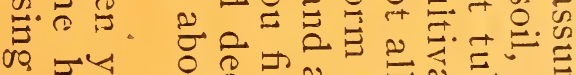

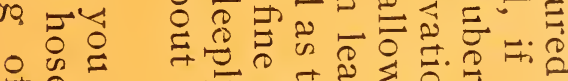
융

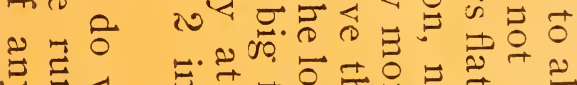

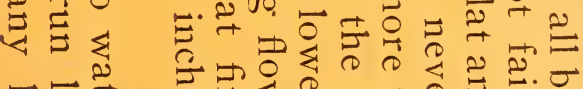

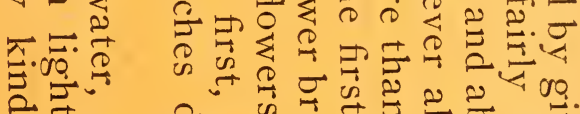
击官 品。

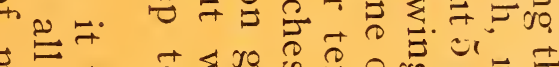

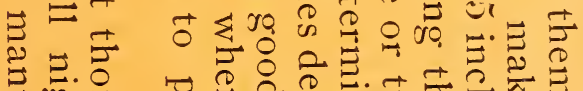

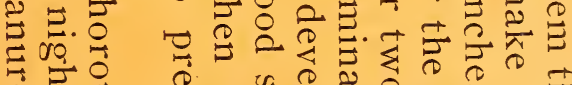

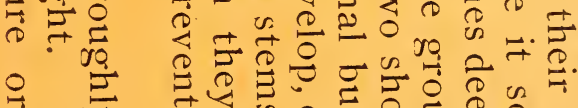
$\rightarrow$ द्ये

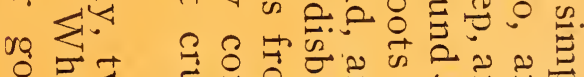

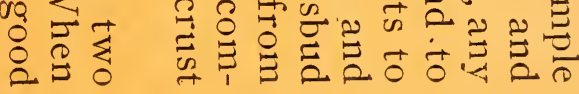



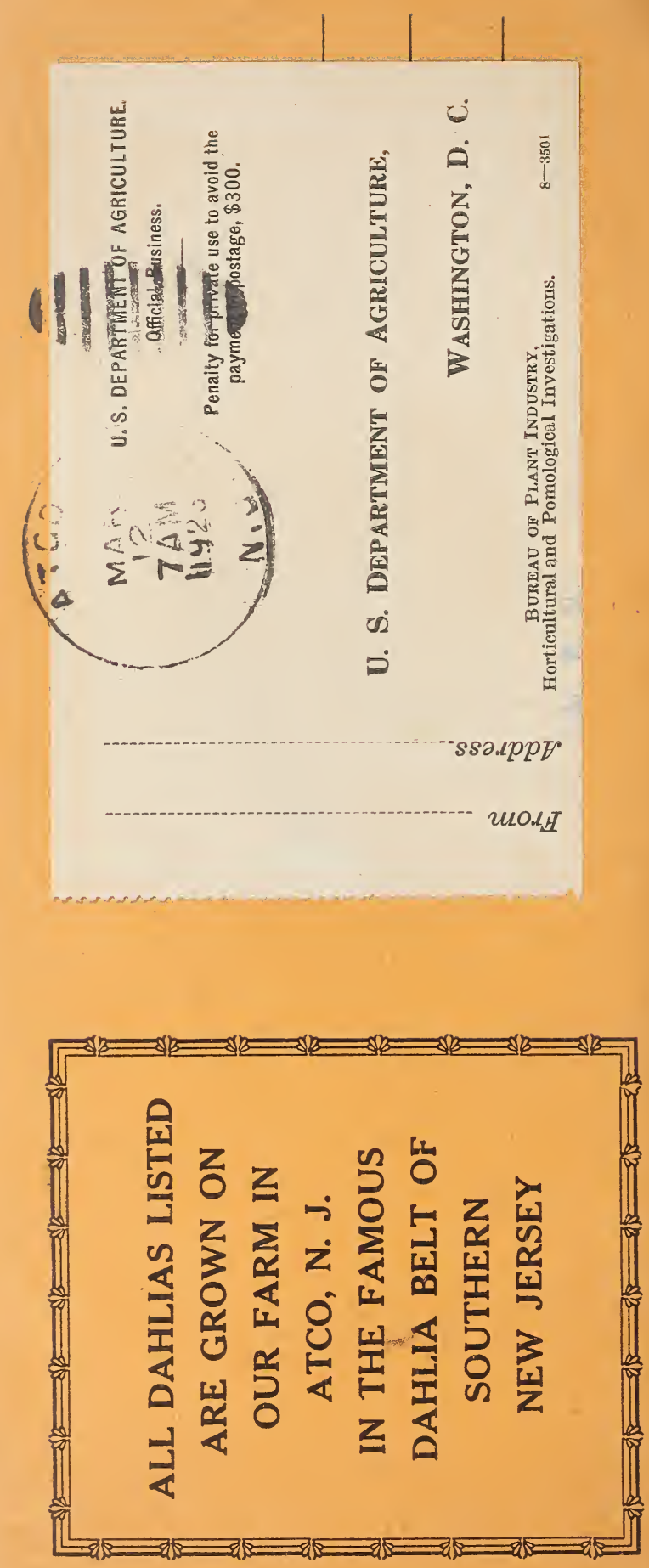